\title{
Transfer Pricing for Taxation of Transnational Corporations under Innovative Economy Conditions
}

\author{
V.V.Velikorossov ${ }^{1,}{ }^{*}$, L.A. Chaykovskaya ${ }^{1}$, S.A. Filin ${ }^{1}$ \\ ${ }^{1}$ Department of Management, Plekhanov Russian Economic Universit, Stremyanny Lane, 36, \\ Moscow, Russia \\ ${ }^{*}$ Corresponding author
}

Keywords: Transfer Price, Profit, Pricing, Transnational Corporations, Taxation, Separate Accounting, Proportional Division.

Abstract: In article questions of state regulation of a system of taxation of multinational corporations in the conditions of economic globalization, advantage of placement of production and the centers of profit in the countries with the different level of taxation are analyzed. The Russian experience of taxation of transnational corporations is analyzed. The method of calculation of a contribution to formation of income of different jurisdictions of the corresponding factors of production is offered.

\section{Introduction}

Transfer pricing allows transnational corporations (TNCs) to minimize tax payments: in the process of corporate international tax planning, aggregate tax payments of the group are minimized, which are the sum of local taxes paid in the countries where the affiliates of the group are located, as well as taxes on the company in the parent company's residence jurisdiction. At the same time, the state loses a significant part of tax revenues, loses payments to the state budget [1]. In order to combat money laundering, the tax authorities of different countries began to exchange tax information about the activities of such companies. At the same time, tax administration in the international sphere concerning coping with money laundering and ensuring tax transparency is becoming more and more labor-intensive and resource-intensive, intensifying the activities of tax administrations, which is due to the need to check and analyze the ever-increasing amount of data. This leads to an increase in budget expenditures on participation in the international automatic exchange of tax information and the upkeep of the increasing apparatus of tax administrations.

\section{Foreign Experience in Taxing TNCs}

The latter constitute consolidated global financial reporting in accordance with international standards, as well as three-level transfer pricing (TP) documentation according to the OECD standard [2], for the purpose of determining the true profit of TNCs generated in each national tax jurisdiction, which indicates the intention of the states to control TNC in the absence of global regulation of TNCs in general [3].

Within the framework of international taxation, income is recognized as originating from the conduct of labor activities, the provision of services, investments, entrepreneurial activities, each of 
which is taxed according to different methods. . As a result, TNCs manage these sources of income in view of the possibility of classifying them at the lowest possible tax rate. For minimization / tax evasion, TNCs create relevant units, increase the costs of maintaining, remunerating and training the staff of these departments, paying for external consultants, which ultimately further reduces its tax base. The tax received by each state from the activities of TNCs is also largely determined by the experience of lawyers and accountants $[4,15]$.

In accordance to the European Commissioner for Economic Affairs, Pierre Moscovici: "... this is not the base rate that leads to tax evasion, but schemes that facilitate the transfer of profits" (to other jurisdictions). According to expert estimates [5], the average rate of corporate taxes paid by US corporations abroad is $6 \%$. Withdrawing taxable profits from the United States, these companies underpaid the US budget about \$ 620 billion. As part of a partial solution to this problem in the United States, as a result of the tax reform carried out in 2017, the base corporate tax rate was reduced from 35 to $21 \%$, companies had the opportunity to repatriate foreign profits by paying a one-time tax at a rate of $15.5 \%$.

The methodology of taxation of TNCs is currently based on bringing each legal entity within it to some hypothetical model of an independent organization acting, as it were, in a free competitive market, on the principle and standard of "outstretched hand" (The total income of TNCs is distributed between its branches based on the accounting data of each branch and the "arm's length" principle for intra-company trading) TNCs. would be subject to subsequent procedures for adjusting income, retraining, the basis for the development of international measures to counter evasion of TNCs from taxes. The "outstretched hand" principle corresponds to the international trade model in which production was carried out in one jurisdiction and sale in another. This method does not take into account the desire of TNCs to maximize global profits, rather than the profits of each of its separate divisions, and that affiliated companies can initiate actions that change the value and profits from financial intercompany operations [5]; the method provides for setting not a market price, but price that is close to the price that can be considered normal, taking into account circumstances and facts (there is a transition from the concept of "price identity" (from objective quantitative analysis) to the concept "price normality" (to subjective qualitative analysis))). As a result, the method based on the "outstretched arm" principle does not ensure a fair distribution of income between the interacting parties [6].

In the case of TP the national tax authorities applied the following methods are: comparable profitability / market prices, subsequent sale prices, cost-based, profit distribution, etc.

Although the OECD Model Convention is based on an accurate definition of the boundaries of active business activities carried out in a particular country (institution of permanent representation, criteria, concepts, etc.), it does not use the concept of "global income of TNCs" and considers its members as separate entities being in business relations with each other on the basis of activity on a market basis: the problem of dual legal non-taxation appears [7]. Options for tax evasion in TNCs reduce the tax burden and the country - the source of income, and the country of residence.

The OECD BEPS Plan [8] and the Anti-Tax Avoidance Directive developed by the European Commission Directive contain key standards and recommendations that countries use in various ways when forming national rules in accordance with the objectives of their tax policy. The states 'various integration of the BEPS measures and the ATAD Directive into national laws beneficial to this jurisdiction are now a global trend, causing distortions and tax "loopholes" and business barriers that TNCs can use to evade taxes.

Currently, there have been changes in technology (including financial), digitalization of the economy, the development of electronic commerce, services, the use of cryptocurrency [9], automation of taxation and accounting through improved software products and applications, the introduction of innovative technologies in taxation and accounting [10], the presence in the 
structures of TNCs of virtual permanent missions is difficult to control networks of tax receptions. The modern concept of a permanent establishment does not reflect the specifics of modern business models and the digital economy as a whole. In the latter, the principle of "independent subject" does not work: it is impossible to apply such classical criteria of economic binding to the state as the existence of a property base and personnel (criteria of physical presence). Digital trade allows for the delivery of goods and services abroad, but it is here that the market is formed (sales take place, users are found, cost is created and revenue is generated). Legislation on controlled foreign companies acts as an association of tax invoices of TNCs in the framework of the modern accounting principle, but contrary to the principle of "independent subject" of tax agreements. The application of this legislation involves taxation of income of a foreign company at the shareholder level, even if it does not distribute dividends, despite the fact that such a company is a separate object for tax purposes. The methods of "controlled transaction" do not allow in this case to determine the "binding" of taxation to this jurisdiction, since functional analysis of virtual presence is impossible.

The traditional approach to the separation of the international tax base is as follows [11]: 1) the source countries (where income is formed) and the resident country (where the investor lives) have a harmonized and legal tax jurisdiction; 2) corporations and their investors are subject to separate taxation; 3) investors and corporations are taxed on the basis of their income (using the TP rules). However, separate taxation of corporations and their shareholders suppresses incentives for corporate financing at the expense of retained earnings or liabilities and investing in new corporate capital.

The problems associated with the shift of profits and TP with separate accounting (SA), suggest the introduction of a tax accounting system similar to that used in national US companies [12]. If divisions of the company are located in different states, the tax authorities do not rely on the SA data, but use formulas for calculating the tax base for each state. They distribute assets, sales and wages for each state in which the company operates, and then use these components to calculate the tax base in this state [13]. This system of taxation of TNCs provides the conditions under which TNCs cannot avoid taxation in any state, as long as they conduct any activity in it, called the "principle of proportional separation" (PPS). The methods of functional and factual analysis used for the implementation of the "outstretched hand" principle are forms of the inter-jurisdictional PPS of the global tax base of TNCs, taking into account the functions and risks of TNC structures, calculated by the formula as a proportion, the initial elements of which are revealed by subjective (qualitative) analysis.

\section{Russian Experience in Taxing TNCs.}

The taxation of incomes of TNCs in Russia uses the documents of the OECD tax legislation and, as in most countries, is based on data from the Republic of Uzbekistan. Through the TP, prices are set that are subject to special tax control, since there is reason to believe that their value is not determined by the parties to the transaction through the market and not to achieve a commercial goal, but solely in order to reduce the tax burden.

Although the PPS principle is perceived as a way to reduce / eliminate the interest of using the DTP to shift incomes to countries with low taxation, its use can create price distortions, which must be taken into account. At the same time, experts predict the transformation of intra-company transfer of tangible assets to the corresponding transfer of intangible assets (IA) and services as the main form of intra-company trade [4]. The problems of determining the TP and the tax base at the same time are significantly more complicated and, as follows from [8], this is similar in terms of IA to proportional imputation of profit data. 
Since the nature and functioning of TNCs objectively manifest themselves in specific economic conditions, tax regulation should adequately reflect this specificity. When choosing the "best" method in accordance with paragraph 4, Art. 105.7 of the Tax Code of the Russian Federation uses the "method, which, taking into account the actual circumstances and conditions of the controlled transaction, makes it possible to make the most reasonable conclusion about the compliance or noncompliance of the price applied in the transaction with market prices". In particular, the paper [5] analyzes the method of corporate taxation of TNCs based on a fractional method for determining profits (global formula apportionment), including: 1)consolidation of TNCs in the category of corporate taxpayer with a special tax regime and tax administration at the level of specialized interregional tax inspection, procedures for their international registration and maintenance of the international registry of TNCs; 2) determination in the TNC of a "responsible taxpayer" for tax accounting and payment on the basis of the tax rates - profit tax that are valid in a particular tax jurisdiction (if there is a group enterprise in this jurisdiction); 3) the addition of a Multilateral Convention to Implement Tax Treaty Related Measures to Prevent BEPS on the allocation of state rights to tax certain types of income (global incomes of TNCs) from resident extraterritorial activities between countries based on the proposed fractional method; 4) the tax treatment and administration of the corporate taxpayer in a particular jurisdiction should be the same for TNCs, regardless of whether the jurisdiction is the country of origin or the host country; 5) determination of the tax base of TNCs falling into a specific tax jurisdiction, based on the performance of all its structures in the form of a global income of TNCs, in proportion to the share of production factors (labor and capital) and the "revenue" indicator of the economic activities of the entities in this jurisdiction in the total amount of similar criteria for all TNCs.

The global method of preventive maintenance according to the appropriate formula fixes, on the one hand, the income for the country, where the factors of production are identified that contribute to the receipt of income from them in a certain jurisdiction by a relevant type of activity regardless of whether distributed income is received in a given country or abroad. The necessary consistency between such income, having a source in a jurisdiction where these factors are located, and taxing jurisdiction prevails, since only production factors generate income as a result of a certain economic activity. In other words, the company benefited from the privileges provided by the state, where such factors are identified.

The proposed in [5] formula of the global PPS of the tax base of TNCs between jurisdictions does not take into account such production factors as natural resources ("land") and the production factors of the innovation economy - information capital and knowledge capital. The risk of a possible non-realization of the corresponding factor of production is also not taken into account. Therefore, the authors propose the following calculation algorithm.

For a certain tax period, the global profit of a particular TNC belongs to the i-th jurisdiction based on the share of profit accounted for by the last one:

$$
\mathrm{P}_{\mathrm{i}}=\mathrm{P}_{\text {glob }} \mathrm{X} \mathrm{V}_{\mathrm{i}},
$$

where $\mathrm{P}_{\mathrm{i}}$ - the taxable income of the $\mathrm{i}$-th jurisdiction; $\mathrm{P}_{\text {glob }}$ - the total global profit of a particular TNC; $\mathrm{V}_{\mathrm{i}}$ - the share of the global profit of a specific TNC attributed to the i-th jurisdiction, $\%$ determined depending on the share of production factors under this jurisdiction (human capital ("labor"), "capital", natural resources ("land"), information capital capital of knowledge).

To take into account the synergistic effect of the interaction of these factors of production, you can use the neoclassical production function, for example, the Cobb-Douglas function, interpreted as follows: 


$$
\mathrm{Y}=\mathrm{F}(\mathrm{I}, \mathrm{L}, \mathrm{T})=\mathrm{A} \cdot \mathrm{K}^{\alpha} \cdot \mathrm{F}^{(1-\alpha)},
$$

where for a certain tax period $(\mathrm{t}) \mathrm{Y}$ the income of the i-th jurisdiction from factors of production that are in this jurisdiction; $\mathrm{L}$ - contribution to the formation of income of the $\mathrm{i}$-th jurisdiction of the production factor "labor" in the form of human capital; I - contribution to the formation of income of the i-th jurisdiction of investments (the sum of production factors "capital" and natural resources ("land")) in the form of tangible assets; T - contribution to the formation of income of the i-th jurisdiction of technological progress (the sum of information capital and knowledge capital) in the form of IA, providing the level of productivity and efficiency of using other factors of production; F - attractiveness in the form of income of the i-th jurisdiction as a cost-effective service, the change in the annual growth rate of which is defined as: $F=F_{0} \times e^{v t} ; \alpha$ is the maximum value of the share $(\rho)$ of investments (I), while $(\rho)$ is a control parameter that is set at the initial time at any level from the range of permissible values $(0<\rho<1)$ and is constant in time; $v$ is the annual growth rate of the number of people employed in production), is within the limits: $(-1<v<1)$, and is constant in time.

Analysis of these factors allows to get a share of their quantitative contribution to the formation of income of the $\mathrm{i}$-th jurisdiction in the share of the global profit of a specific TNC $\left(\mathrm{V}_{\mathrm{i}}\right)$ attributed to the i-th jurisdiction using marketing research methods, for example, based on the research of IMF experts on the dependence of economic growth on various factors production, performed on the basis of aggregated production functions R. Solow [14].

According to [14], trends in the USA every 10 years are: T $-11.6 \%, \mathrm{~L}--8.9 \%$, capital (I) - $0.6 \%$; in the EU: T $-9.9 \%$, L - $-26.5 \%$, capital (I) - $-2.2 \%$; in Japan: T - 17.6\%, L - $-40.7 \%$, capital (I) $--7.6 \%$. Therefore, with a certain degree of certainty, the share of factors that determined the economic growth of the USA in the 2010s: T $-43.1 \%$, L $-28.7 \%$, capital (I) $-28.2 \%$, EU in the 1990s years .: T - 56.3\%, L - 5.4\%, capital (I) - 38.3\%; Japan: T - 59.5\%, L - 5.0\%, capital (I) $35.5 \%$.

To compare the results obtained, we give the proportion of factors that determined the actual economic growth of the USA over 50 years: T $-49 \%, \mathrm{~L}-27 \%$, I $-24 \%$. That is, the probability of deviation of the calculated indicators for 10 years from the indicators for a long period - 50 years is for the United States: $(\Delta \mathrm{T} / \mathrm{T}) \times 100 \%-12 \%,(\Delta \mathrm{L} / \mathrm{L}) \times 100 \%-6.3 \%,(\Delta \mathrm{I} / \mathrm{I}) \times 100 \%-17.5 \%$. These data can be taken as a measure of the risk of a possible deviation of the forecast figures (for example, for the 2020s) from the actual ones. This discrepancy is explained by Kondratieff waves lasting 40-60 years, having a different level of investment and innovation activity as compared with the average (industrial) cycles (7-12 years) of Zhuglar included in it.

Therefore, with a certain degree of certainty, using the example of three regions, one can consider these figures, taking into account the risk factor associated with uneven development (turbulence) during the period of the corresponding Kondratieff wave, as contributing to the income generation of the i-th jurisdiction of the relevant production factors:

$$
\mathrm{P}_{\mathrm{i}}=\mathrm{P}_{\mathrm{Glob}} \times \mathrm{V}_{\mathrm{i}} \times \mathrm{R}_{\mathrm{i}},
$$

where: $\mathrm{R}_{\mathrm{i}}$ - the probability of deviation of the calculated indices of the corresponding factor of production from the actual ones.

To account for local and regional benefits provided to investors, the proposed formula can be used to determine the share of the global profits of TNCs falling on the territory of the relevant region.

Recommendations. In theoretical and practical aspects of international taxation the following points are necessary:

1) the development of approaches and methods that take into account the possibility of 
distributing the tax base of TNCs between jurisdictions without using the criteria of physical presence in the country - the market for TNC products;

2) economically justified territorial distribution of the taxable base of TNCs, in which income is taxed in the state where it is created. This can be an effective tool to ensure the stability of state budgets, both from tax evasion by TNCs and to excluding international double taxation.

\section{Conclusions}

1. The development of TNCs, the systemic unity of their "country fragmentation" and global functioning under taxation objectively contribute to the implementation of the "tax evasion" mechanism through the use of the WTC, forcing states to improve and harmonize tax legislation and control, to form a taxation methodology for TNCs with the introduction of increasingly complex methods struggle with the "erosion" of the tax base, the withdrawal of profits from taxation. At the same time, these methods often do not meet the classical principles for taxes (economy, simplicity, certainty, efficiency and equity), and taking into account the economies of scale of A. Laffer included in international tax competition states that have strict mechanisms to counteract the payment of TNCs taxes may lose taxpayers and investments.

2. The proposed method of calculating the contribution to the formation of income of the i-th jurisdiction of the relevant factors of production can be used in the framework of local tax regulation methods of consolidated groups of resident taxpayers based on the PPS principle, which positions it as ensuring a fair distribution of the tax base and tax amounts among state budgets.

\section{References}

[1] Velikorossov, V.V. and Makashina, O.V. (2018). Use of foreign experience of bankruptcy of territories. Development of integration processes in economy of Russia. Moscow: RUSAYNS. 2018, 103-108.

[2] Guidance on Transfer Pricing Documentation and Country-by-Country Reporting (2014), 0ECD/G20 Base Erosion and Profit Shifting Project, OECD Publishing.

[3] Polezharova, L.V. and Vinogradova, A.V. (2015). Evolution of regulation of transfer pricing in Russia: yesterday, today, tomorrow. Economy. Taxes. Right, 2, 120-126.

[4] Krasnov, I. (2013). Transfer pricing and international practice of taxation of multinational corporation. Macroeconomic, 53 UEKS (5).

[5] Polezharova, L.V. (2017). Alternative approach in methodology of taxation of multinational corporation: need and opportunity. Economy. Taxes. Right, 5, 134-141.

[6] Kay, J. (1993). Oxford: Oxford University Press. DOI: 10.1016/0263-2373(93)90069-t.

[7] Goncharenko, L.I. (2017). Moscow: Dashkov and Po. 582 p.

[8] Action Plan on Base Erosion and Profit Shifting (2013). OECD Publishing.

[9] Filin, S.A. and Chaykovsky, L.A. (2018). Kriptovalyuta as digital asset: possibilities of account and feature of taxation. Economy and management: problems, decisions, v. 1, 3, 65-79.

[10] Filin, S.A., Chaykovskaya, L.A. and Satymbekova, K.B. (2019). Innovative technologies in accounting. The International accounting, v. 22, 4 (454), 393-408. 
[11] Legislative History of United States Tax Conventions (1962). Volume 4: Model Tax Conventions (Washington, D.C.: U. S. Government Printing Office, 4253.

[12] Okopova, E.S., Voronkova, O.M. and Gavrilka, N.N. (2015). Rostov-on-Don: Phoenix. 416 p.

[13] Velikorossov, V.V., Makashina, O.V. and Donskaya S.L. (2019). The interbudgetary alignment of income of budgets for increase in stability of economic development of the country//Economy and management: problems, decisions, v. 1 (88), 4, 31-38.

[14] World Economic Outlook, Safeguarding Macroeconomic Stability at Low Inflation (October 1999). A Survey by the Staff of the International Monetary Fund, International Monetary Fund, p. 74.

[15] Khachaturyan M.V., Klicheva E.V., Velikorossov V. V. (2019) Digital Mechanisms of Development of Possessory Risk Management Systems under New Economic Conditions. Proceedings of the 2019 International Conference on Politics, Economics and Management (ICPEM 2019). Lecture Notes in Economics, Management, and Social Sciences. Clausius Scientific Press, Vol. 5. P. 6-10 